\title{
Melihat Peran Perantara dalam Kasus Penyebaran Video Non-Konsensual dengan Kerangka Contextual Integrity
}

\author{
ldha Saraswati \\ Peneliti PurpleCode Collective \\ *Penulis Koresponden: jatisaras@gmail.com
}

\section{ABSTRAK}

Jumlah kasus kekerasan berbasis gender online atau KBGO selama masa pandemi dilaporkan meningkat. Penambahan jumlah pengguna internet serta kian masifnya tranformasi digital selama masa pandemi dipandang berkontribusi dalam peningkatan kasus KBGO tersebut. Kekerasan berbasis gender yang selama ini sudah marak terjadi di ranah offline menemukan ruang baru di dunia online sehingga kian mengancam keamanan, kesehatan dan keselamatan perempuan. Dalam kasus KBGO, dua pihak yang paling banyak dibicarakan adalah pelaku dan korban. Namun, pembicaraan tersebut melupakan pihak lain yang juga berpengaruh penting dalam terjadinya kekerasan, yakni platform digital yang menjadi wadah maupun memfasilitasi peristiwa kekerasan. Platform digital seperti media sosial tercatat menjadi salah satu medium terjadinya KBGO. Tulisan ini memaparkan peran platform digital sebagai perantara dalam kasus kekerasan, khususnya KBGO, dengan menerapkan kerangka contextual integrity yang diajukan Nissenbaum (2010) pada kasus penyebaran video intim non-konsensual yang menimpa GA dan GL. Tulisan ini menunjukkan bahwa melalui sistem dan kebijakan layanannya, pihak perantara turut berperan dalam mendorong terjadinya KBGO.

Kata Kunci: video intim non-konsensual; KBGO; platform digital; perantara

\section{ABSTRACT}

The number of online gender based violence $(O G B V)$ cases in Indonesia are reportedly increasing during the pandemic. The increasing number of internet users and the massive digital transformation during the pandemic has contributed to the escalation in OGBV cases. Gender-based violence has found a new space in the online world, thus threatening women's security, health, and safety. In the OGBV case, the two parties that has been discussed the most were the perpetrators and the victims. However, the discussion forgot about the other party that also had an important influence, namely the digital platform. Digital platfarm like social media has become the medium for OGBV.This paper describes the role of the digital platform as an intermediary party for communication exchange in the cases of online violence, especially OGBV, by applying the contextual integrity framework proposed by Nissenbaum (2010) in the dissemination of non-consensual intimate videos of GA and GL cases. This paper shows that through its system and policies, digital platforms play significant role in facilitating $O G B V$.

Kata Kunci: non-consensual intimate video; OGBV; digital platforms; intermediary

\section{PENDAHULUAN}

Selama masa pandemi Covid-19, kasus kekerasan yang menyasar perempuan di ranah online di Indonesia dilaporkan meningkat. Kasus semacam itu merupakan bagian dari kekerasan yang difasilitasi teknologi informasi dan komunikasi. Istilah yang kerap digunakan untuk menyebut kasus-kasus semacam itu adalah kekerasan berbasis gender online atau KBGO. Selain istilah itu, 
sejumlah pihak di Indonesia, termasuk Komisi Nasional Perempuan, saat ini menyebutnya sebagai kekerasan berbasis gender siber atau KBGS. ${ }^{1}$

Berdasarkan Catatan Tahunan Komisi Nasional (Komnas) Perempuan 2020, angka kasus KGBS yang dilaporkan langsung ke Komnas Perempuan naik dari 241 kasus pada tahun 2019 menjadi 940 kasus pada 2020. Laporan kasus serupa ke sejumlah lembaga layanan mitra Komnas Perempuan juga naik dari 126 kasus pada 2019 menjadi 510 kasus pada $2020{ }^{2}$

Seperti namanya, KBGO merupakan bagian dari kekerasan berbasis gender (KBG). Untuk itu, KBGO perlu dilihat dalam konteks ketidaksetaraan gender akibat budaya patriarki yang menempatkan perempuan maupun kelompok gender minoritas lainnya dalam posisi subordinat. Istilah KBG sendiri sering digunakan secara bergantian dengan istilah kekerasan terhadap perempuan (violence against women/VAW). Namun, dua istilah itu sebenarnya punya definisi yang berbeda.

Deklarasi tentang penghapusan kekerasan terhadap perempuan Majelis Umum Perserikatan Bangsa-Bangsa 1993 mendefinisikan kekerasan terhadap perempuan sebagai setiap tindakan kekerasan berbasis gender yang menghasilkan atau memungkinkan akan mengakibatkan kekerasan dalam bentuk fisik, seksual, psikologis atau penderitaan terhadap perempuan termasuk ancaman, paksaan atau perampasan kebebasan perempuan secara sewenang-wenang baik yang terjadi di depan umum atau dalam kehidupan pribadi. Adapun KBG merujuk pada setiap tindakan kekerasan yang ditujukan terhadap individu maupun kelompok berdasarkan gender mereka.

UN Women ${ }^{3}$ menyebut akar dari KGB adalah ketidaksetaraan gender, penyalahgunaan kekuasaan dan norma-norma kekerasan. Istilah ini digunakan untuk memberi penekanan pada fakta bahwa struktur kuasa berbasis gender yang tidak setara telah menempatkan perempuan dan remaja perempuan dalam risiko kekerasan berlapis. Selain itu, dengan istilah KBG, laki-laki dan remaja laki-laki juga bisa menjadi korban meskipun secara umum korban terbesarnya adalah perempuan dan remaja perempuan. Istilah ini juga kerap digunakan untuk mendefinisikan kekerasan yang dialami kelompok LGBTQI+ akibat posisi mereka dalam norma gender dominan. Dengan definisi

1 Sebagai fenomena yang relatif baru bersamaan dengan perkembangan teknologi informasi dan komunikasi yang masih akan terus berlangsung, ada banyak istilah untuk menamai kekerasan terhadap perempuan di ranah online. Dalam catatan sekretariat Perserikatan Bangsa-Bangsa atas laporan Special Rapporteur on violence against women Dubravka Simonovic yang dipublikasikan pada 2018, disebutkan bahwa di tingkat internasional ada sejumlah istilah untuk menyebut fenomena kekerasan ini, dan istilah-istilah itupun masih terus berkembang definisinya. Ada yang menyebutnya kekerasan online, kekerasan digital, kekerasan siber dan sebagainya. Dalam laporan itu, istilah yang dipandang bisa merangkum fenomena kekerasan yang terjadi adalah "kekerasan yang difasilitasi teknologi informasi dan komunikasi terhadap perempuan (ICT-facilitated violence against women)" serta "kekerasan online terhadap perempuan" sebagai versi sederhananya. Lihat $C T R L+A L T+D E L K B G O$ !, seri buku saku KBGO yang diterpitkan PurpleCode Collective tahun 2020.

2 Komnas Perempuan (2021), Perempuan dalam himpitan pandemi: Lonjakan kekerasan seksual, kekerasan siber, perkawinan anak, dan keterbatasan penanganan di tengah Covid-19. Catatan kekerasan terhadap perempuan tahun 2020.

3 https://www.unwomen.org/en/what-we-do/ending-violence-against-women/faqs/types-of-violence 
tersebut, kekerasan terhadap perempuan dan remaja perempuan merupakan bagian dari KBG. Kekerasan terhadap perempuan bisa disebut sebagai jenis kekerasan terbesar atau utama dari KBG, namun KGB juga menjadi payung untuk menyebut kekerasan terhadap anak dan laki-laki yang terjadi akibat identitas gender mereka (Aghtaie \& Gangoli, 2014: 6).

KBG bisa terjadi di ranah privat maupun publik sehingga mengancam kebebasan dan keselamatan perempuan, serta menempatkan perempuan dalam iklim yang tidak aman. Senafas dengan itu, KBG yang terjadi di ranah online atau KBGO juga mengancam kebebasan, kehormatan dan privasi korban, sekaligus membatasi kebebasan korban untuk berpartisipasi dalam kehidupan sosial (Citron dalam Suzor et al, 2018: 5). KBGO adalah perpanjangan sekaligus akselerasi dari kekerasan berbasis gender yang selama ini sudah terjadi di ranah offline. Bentuk KBGO ada bermacam-macam. Dalam buku panduan KBGO yang diterbitkan 2020, PurpleCode Collective mencatat ada 14 bentuk KBGO, mulai dari trolling (provokasi melalui komentar yang tajam), penyebaran konten intim non konsensual (video maupun foto), extortion (pemerasan untuk tujuan ekonomi) dan sextortion (pemerasan untuk mendapat kepuasan seksual), online stalking (penguntitan), tech-enabled surveillance (pengawasan), doxing (pelacakan diikuti penyebaran informasi pribadi), outing (pengungkapan identitas gender seseorang tanpa persetujuan), impersonasi (pembuatan akun palsu menggunakan data seseorang), peretasan, pornografi, pornografi anak, manipulasi foto dan video, honey trap (dijebak agar terlibat dalam relasi romantis maupun seksual yang berujung pada pemerasan), dan cyber grooming (menjebak anak di bawah umur hingga mendapat kepercayaan dari korban sebagai tahap persiapan untuk membuat korban bersedia berhubungan seksual). ${ }^{4}$

Meningkatnya laporan kasus KBGO di masa pandemi tersebut setidaknya menunjukkan dua hal. Pertama, kian bertambahnya pemahaman pengguna internet akan adanya KBGO sehingga kian aktif melaporkannya. KBGO sudah terjadi seiring teknologi online itu dikembangkan, namun kesadaran akan adanya jenis kekerasan ini belum lama muncul sehingga pada tahun-tahun sebelumnya laporan yang masuk masih sedikit. Oleh karena itu, berbagai kalangan menyebut bahwa jumlah yang dilaporkan itu merupakan fenomena gunung es karena tidak menggambarkan kondisi yang sebenarnya. ${ }^{5}$ Kedua, peningkatan kasus itu berkaitan erat dengan kian masifnya penggunaan teknologi berbasis internet dalam keseharian masyarakat di masa pandemi. Survei pengguna internet 2019-kuarter II 2020 oleh Asosiasi Penyelenggara Jasa Internet Indonesia (APJII) menemukan bahwa jumlah pengguna internet di Indonesia naik sebesar 8,9 persen dibanding 2018 menjadi 196,7 juta jiwa. Kenaikan jumlah pengguna itu antara lain terjadi karena

\footnotetext{
4 Lihat "CTRL+ALT+DEL KBGO!”, seri buku saku KBGO yang diterpitkan PurpleCode Collective 2020

5 Meskipun angka laporan kasus KBGO naik, Komnas Perempuan mencatat bahwa tingkat respons pengembalian kusioner dari lembaga mitra turun hingga 50 persen dibanding tahun sebelumnya. Dari 757 kuesioner yang disebar pada 2020, hanya 120 lembar yang dikirimkan kembali sehingga sangat berdampak pada kompilasi data. Pandemi Covid-19 dipandang menjadi faktor penyebabnya karena semua pihak membutuhkan waktu untuk beradaptasi dengan sistem kerja online. Dengan demikian, angka yang dilaporkan kemungkinan masih jauh di bawah kasus yang terjadi. Lihat Catatan kekerasan terhadap perempuan tahun 2020, Komnas Perempuan, hal.15
} 
kian meratanya infrastruktur internet serta kian masifnya transformasi digital akibat kebijakan pembelajaran online dan bekerja di rumah selama pandemi Covid-19. ${ }^{6}$

Meningkatnya jumlah pengguna internet di masa pandemi yang beriringan dengan naiknya kasus KBGO menjadi suatu fenomena yang perlu dilihat lebih dalam. Di satu sisi, kekerasan berbasis gender sudah marak sebelum teknologi digital hadir. Dengan demikian, teknologi sebagai perantara pertukaran komunikasi menyediakan ruang lanjutan yang mengamplifikasi kekerasan tersebut. Di sisi lain, sebagai perantara, platform teknologi digital bukanlah sekadar alat yang bebas nilai. Setiap platform memiliki cara kerja dan kebijakan layanan yang turut memengaruhi proses pertukaran pesan di dalamnya. Oleh karena itu, peran teknologi dalam meningkatnya kekerasan online perlu dilihat. Tulisan ini akan menjawab pertanyaan terkait bagaimana peran platform teknologi digital dalam memfasilitasi sekaligus mendorong terjadinya KBGO.

\section{TINJAUAN PUSTAKA}

KBGO atau dalam bahasa inggris online gander based violence (OGBV) merupakan istilah yang semakin sering disebut dalam kurun waktu setidaknya lima tahun terakhir untuk menamai sejumlah kasus kekerasan berbasis gender di ranah online yang kian marak di seluruh dunia. ${ }^{7}$ Seiring dengan itu, literatur yang membahas KBGO di berbagai negara bermunculan. Sejumlah literatur membahas pengalaman korban kekerasan online sebagai salah satu bentuk dari KBGO (misalnya Henry \& Powell, 2014; Ojanen et al, 2015). Ada pula yang membahas peran teknologi dalam kasus KBGO (antara lain Nyst, 2014; Silvia \& Lucia, 2020; Suzor et al, 2019), serta respons perempuan terhadap KBGO (antara lain Vitis \& Gilmour, 2016; Chada, Steiner \& Vitak, 2020).

Di Indonesia, literatur mengenai KBGO masih terbatas. Untuk konteks pandemi, Jatmiko, Syukron \& Mekarsari (2020) menyebut bahwa kemajuan teknologi, peningkatan jumlah pengguna media sosial dan peningkatan intensitas penggunaan media sosial selama masa pandemi telah memperburuk fenomena KBGO di Indonesia. Perempuan menjadi sasaran kekerasan seksual di ranah offline yang berlanjut di ranah online. Ruang siber yang memiliki akselerasi berkecepatan tinggi telah dihegemoni dengan nilai-nilai maskulinitas sehingga menjadi kendaraan bagi hadirnya bentuk kekerasan seksual online hari ini. Kekerasan online tersebut merupakan kombinasi kompleks dari elemen teknis dan praktik sosio-kultural (Jatmiko, Syukron \& Mekarsari, 2020). Selain tulisan tersebut, Christian (2020) membahas sekstorsi sebagai salah satu bentuk KBGO dalam kerangka hukum Indonesia. Sementara Ratnasari, Sumartias \& Romli (2020) mengeksplorasi aktivisme digital dalam mengkampanyekan bahaya KBGO di Indonesia. Pembahasan mengenai aspek peran platform teknologi digital dalam terjadinya KBGO untuk konteks Indonesia masih sangat minim. Oleh karena itu, tulisan ini diharapkan bisa menambah literatur pembahasan KBGO di Indonesia, khususnya terkait peran platform digital sebagai perantara komunikasi dan pesan dalam kasus kekerasan berbasis gender online yang menimpa perempuan.

6 Buletin APJII Edisi 74, November 2020, hal 1

7 Lihat buku saku KBGO terbitan PurpleCode Collective 


\section{METODE DAN KERANGKA PIKIR}

Tulisan ini bertujuan melihat peran platform digital dalam kasus KBGO di Indonesia. Platform digital adalah pihak intermediator atau perantara dalam pertukaran pesan dan komunikasi bagi penggunanya. Menggunakan metode penelitian kualitatif, secara khusus tulisan ini melihat bagaimana peran perantara dalam kasus penyebaran video intim non-konsensual yang menimpa GA dan GL, dua perempuan figur publik di Indonesia. Data diperoleh melalui penelusuran berita dan informasi terkait dua kasus tersebut melalui berbagai media online yang dipublikasikan dalam rentang November 2020 - Maret 2021. Data yang diperoleh kemudian dianalisis menggunakan kerangka integritas kontekstual (Contextual Integrity/CI) dari Helen Nissenbaum (2010) guna melihat peran perantara dalam kasus tersebut. Argumen utama tulisan ini adalah, ketika perantara melanggar privasi pengguna, mereka bisa menjadi pihak yang turut memfasilitasi dan mendorong kekerasan terhadap pengguna.

CI adalah kerangka yang diajukan Nissenbaum untuk menjelaskan makna privasi yang menghadapi tantangan besar akibat perkembangan teknologi teknologi informasi. Teknologi informasi telah dipandang menjadi salah satu ancaman terbesar bagi privasi karena teknologi ini memungkinkan adanya surveillance yang masif, pangkalan data raksasa dan distribusi informasi berkecepatan tinggi secara global. Kerangka ini dikembangkan dalam konteks pertukaran informasi personal. Konsep ini tidak berniat memberikan penjelasan utuh tentang privasi, melainkan menyediakan kerangka yang bisa dikembangkan sebagai model untuk mengevaluasi aliran informasi antaragen (individu maupun entitas lainnya). Dalam konteks ini, Nissenbaum menyatakan bahwa setiap orang punya hak atas privasi. Namun, itu bukanlah hak untuk mengontrol informasi personal maupun hak untuk mengakses informasi yang dilarang, melainkan hak untuk hidup dalam dunia yang memungkinkan harapan rasional setiap orang akan aliran informasi personal yang pantas bisa terpenuhi (Nissenbaum, 2010: 231).

Dalam kerangka CI, mengetahui konteks dari privasi sangatlah penting. Konteks menjadi dasar dalam menganalisis dan mengevaluasi apakah informasi yang dikumpulkan dan disebarkan sudah pantas menurut norma yang berlaku dalam konteks tertentu (Nissenbaum et al, 2007). Kunci utama konsep ini adalah norma informasional relatif sesuai konteks (context-relative informational norms, selanjutnya disebut norma informasional). Konteks adalah situasi sosial yang hadir pada saat tertentu, yang bisa berubah setiap saat. Dalam kehidupan sehari-hari, seseorang bisa menemukan dirinya berada dalam banyak konteks yang berubah-ubah. Norma informasional ini bisa dilihat dari empat parameter:

a. Konteks: situasi sosial ketika komunikasi terjadi. Ketika seseorang berada di rumahnya sendiri, ia punya harapan bahwa apa yang dikomunikasikan di rumah merupakan privasi.

b. Aktor: merupakan entitas yang terlibat komunikasi dalam situasi tertentu. Ada tiga jenis aktor: pengirim informasi, penerima informasi dan subyek informasi. Pengirim dan penerima informasi bisa berupa individu, kelompok maupun entitas lain.

c. Atribut: tipe informasi yang muncul dalam konteks tertentu. Contoh: ketika berkomunikasi dengan teman, seseorang bisa membagikan detail hubungan dengan 
pasangannya; ketika berhubungan dengan bank, ia akan membagikan informasi terkait pemasukan bulanan; ketika seorang dosen berkomunikasi dengan mahasiswa, yang dibahas adalah nilai mahasiswa, dan sebagainya.

d. Prinsip transmisi: batasan yang berlaku dalam aliran informasi dari satu pihak ke pihak lainnya dalam konteks tertentu. Ini mengacu pada syarat dan kondisi seperti apa suatu informasi bisa dibagikan atau tidak bisa dibagikan.

\section{PEMBAHASAN}

\section{Peran Perantara dalam Kasus Kekerasan}

Peran platform teknologi sebagai perantara pesan dalam kasus kekerasan online, khususnya yang menyasar perempuan maupun kelompok minoritas gender, telah dibahas dalam sejumlah literatur. Kekerasan online yang muncul itu berhubungan erat dengan pelanggaran privasi yang dilakukan oleh perantara.

Sekilas memang dalam kasus KBGO peran perantara itu seakan-akan tidak ada, karena mereka tidak berkaitan langsung dengan relasi yang dijalin pengguna (antara korban dengan pelaku KBGO). Selain itu, mereka tidak punya kewenangan secara formal untuk memberi sanksi pada pelaku kekerasan melalui layanan mereka. Meskipun demikian, bukan berarti bahwa mereka tidak punya peran dalam KBGO (Paven dalam Marie \& Vitis, 2017: 63). Walaupun perannya tidak terlihat sangat jelas, perantara itu bisa menjadi fasilitator kekerasan, atau sebaliknya bisa berperan aktif dalam upaya mencegah dan melindungi pengguna dari potensi KBGO. Oleh karena itu, perantara bukanlah aktor yang netral. Melalui kebijakan layanannya (terms of service), perantara menentukan dasar bagi perilaku dan konten online yang bisa diterima sehingga mereka menjadi aktor yang punya dampak signifikan dalam kasus KBGO (Paven dalam Marie \& Vitis, 2017: 64).

Kebijakan layanan Facebook terkait penerapan identitas tunggal, misalnya, dianggap tidak sensitif terhadap identitas kelompok LGBTQ sehingga memperpanjang kekerasan yang dialami oleh kelompok ini (Werbin, Lipton \& Bowman, 2017: 30). Selain platform, teknologi surveillance berbasis internet juga dipandang menambah kompleksitas ancaman kekerasan online terhadap perempuan. Global Positioning Systems (GPS) yang menyediakan posisi real time seseorang bisa digunakan pelaku kekerasan untuk melacak korban (Southworth dalam Mason \& Magnet, 2012: 107). Teknologi pelacakan sederhana juga diterapkan di platform media sosial seperti Facebook, dan Facebook kerap mengubah kebijakan privasinya dan perangkat baru dalam platformnya tanpa memberi tahu pengguna sehingga menambah kerentanan pengguna (Mason \& Magnet, 2012: 108).

Dari sisi teknologi, Bayta dan Nissenbaum (1996) menyimpulkan bahwa sistem komputer mengandung bias. Bias dalam sistem komputer ini didefinisikan sebagai sistem komputer yang mendiskriminasi individu maupun kelompok untuk kepentingan pihak lain secara sistematis dan tidak adil (Bayta \& Nissenbaum, 1996: 3). Ada tiga bias dalam sistem komputer, yakni bias preeksis, bias teknis dan bias yang muncul ketika sistem itu digunakan (emergent bias). Bias pre-eksis berakar dari sistem yang ada di masyarakat baik itu institusi, pratik maupun perilaku sosial, termasuk kecenderungan personal yang memengaruhi desain sistem komputer. Diskriminasi berbasis gender masuk dalam kategori ini. Bias teknis berangkat dari batasan dan pertimbangan 
teknis dalam pengembangan sistem komputer. Ini bisa dilihat dari keterbatasan teknologi komputer termasuk perangkat keras dan lunak, algoritma dan sebagainya. Sedangkan emergent bias merupakan bias muncul ketika sistem komputer yang sudah jadi dioperasikan pengguna. Tampilan muka sistem komputer, misalnya, akan sangat merefleksikan kapasitas, karakter dan kebiasaan penggunanya (Bayta \& Nissenbaum, 1996: 5-6). Berbagai bias ini berkontribusi pada peran teknologi, dalam konteks ini platform digital seperti media sosial, dalam memfasilitasi maupun mendorong kasus kekerasan terhadap penggunanya.

Di lihat dari aspek regulasi, isu mengenai tanggung jawab hukum perantara (intermediary liability) juga sudah menjadi wacana di Indonesia, khususnya ketika kasus tindak pidana eksploitasi seksual dengan memanfaatkan platform media sosial seperti Twitter, Facebook, WhatsApp dan penyedia domain kian marak (Ahsinin, 2017: 2). Dalam konteks pidana eksploitasi seksual online, terdapat tiga aktor utama, yakni pihak yang memulai kekerasan dengan mengunggah konten tertentu. Ini adalah pelaku utama. Kedua, pihak yang dengan sengaja maupun tidak sengaja (ceroboh atau lalai) mengunduh, meneruskan, atau membagikan data atau gambar yang melanggar tersebut. Ketiga, perantara internet yang platformnya digunakan untuk melakukan kekerasan secara online (Aziz, Zaizana Abdul dalam Ahsinin, 2017: 10). Dengan demikian, dari aspek hukum, perantara punya peran dalam kekerasan yang dialami penggunanya.

\section{Kerangka $\mathrm{Cl}$ dalam Kasus GA dan GL}

Penyebaran video intim non konsensual dialami oleh GA dan GL di masa pandemi. Kasus yang menimpa kedua perempuan tersebut menjadi perhatian masyarakat karena mereka merupakan figur publik yang memiliki jutaan pengikut di media sosial. Hingga tulisan ini disusun, kasus hukum terkait kasus GA maupun GL masih bergulir.

Video intim GA menyebar di platform Twitter pada awal November 2020. Seiring bergulirnya video tersebut, tagar yang terkait dengan GA sebagai sosok yang diduga menjadi pemeran dalam video tersebut sempat menjadi trending topik untuk Twitter Indonesia. Video yang direkam pada 2017 tersebut sempat bertahan selama beberapa saat di Twitter sehingga sempat menyebar ke sejumlah platform lain, sebelum akhirnya diturunkan. Desakan yang kuat dari masyarakat membuat kasus ini berlanjut ke ranah hukum. ${ }^{8}$ Pihak kepolisian menangkap sejumlah orang yang menjadi pemilik dari akun-akun Twitter yang diduga menjadi penyebar awal video tersebut. Namun, kasus hukumnya tak berhenti di situ. GA yang diduga menjadi sosok dalam video tersebut juga dimintai keterangan dan akhirnya ditetapkan sebagai tersangka bersama rekannya yang juga ada di dalam rekaman video tersebut. ${ }^{9}$ Penetapan GA sebagai tersangka mendapat respons beragam dari masyarakat. Di kalangan pemerhati hak perempuan, penetapan tersebut dinilai

8 Pada 8 November 2020, sejumlah advokat melaporkan penyebar video GA ke Kepolisian Daerah Metro Jaya dengan menyertakan barang bukti berupa nama-nama akun media sosial yang gencar menyebarkan video tersebut, https://news.detik.com/berita/d-5258259/timeline-kasus-video-syur-hingga-akhirnya-gidel-diperiksa-polisi, $\quad 17$ November 2020, diakses pada 20 Maret 2021.

9 https://megapolitan.kompas.com/read/2020/12/29/13573531/artis-gisel-anastasia-ditetapkan-sebagai-tersangkakasus-video-syur, 29 Desember 2020, diakses 20 Maret 2021. 
bermasalah karena GA sebenarnya merupakan korban dalam kasus tersebut. Alih-alih ditetapkan sebagai tersangka, GA yang video pribadinya disebarluaskan tanpa persetujuan mestinya mendapat perlindungan. ${ }^{10}$

Beberapa bulan setelah kasus video GA, kasus sejenis menimpa GL. Video intim pribadinya menyebar di Telegram untuk kemudian menyeberang ke Twitter tanpa persetujuan pada Februari 2021. GL melaporkan penyebaran video itu ke pihak kepolisian karena ada unsur pemerasan dari salah satu pihak yang menyebarkan videonya. Pada Maret 2021, pemilik akun Instagram yang mengirim pesan pemerasan terhadap GL sudah ditangkap polisi, ${ }^{11}$ demikian juga dengan sejumlah pemilik akun Twitter yang diduga menjadi pihak awal penyebar video GL. ${ }^{12}$ Dalam konteks kasus hukum yang berlangsung, sampai tulisan ini disusun GL tidak ditetapkan sebagai tersangka seperti GA.

Dari aspek regulasi yang berlaku di Indonesia saat ini, dua pihak yang menjadi sorotan utama dalam dua kasus tersebut adalah pembuat dan penyebar video. Pada kasus video GA, pihak-pihak yang paling awal menyebarkan video tersebut sudah ditangkap. Kemudian, GA dan rekannya yang ada dalam video tersebut juga telah ditetapkan sebagai tersangka. Penyebar utama video dari telepon seluler milik GA hingga sampai ke pelaku yang menyebar video tersebut ke Twitter masih ditelusuri. Adapun dalam kasus video GL, pihak penyebar video ke Telegram dan Twitter juga telah ditangkap, demikian pula dengan pemilik akun yang mengirim ancaman bermotif pemerasan melalui Instagram. Sedangkan pihak pembuat dan penyebar utama video tersebut juga masih dicari.

Di luar pihak pembuat dan penyebar video, elemen-elemen lain yang berperan dalam penyebaran video GA dan GL juga perlu dilihat. Kerangka CI dari Nissenbaum, khususnya parameter norma informasional dalam suatu konteks komunikasi, akan bisa menunjukkan elemen-elemen lain tersebut.

Dari sisi konteks, video GA dibuat/direkam sendiri oleh GA menggunakan kamera ponselnya untuk kebutuhan pribadi atau koleksi pribadi. Menurut pengakuannya, video itu hanya pernah dibagikan kepada satu orang yang sosoknya juga ada dalam video tersebut. Dengan demikian, video tersebut tidak pernah dimaksudkan untuk ditonton pihak lain selain dua orang yang berada di dalamnya. Adapun dalam kasus video GL, sampai saat ini belum ada penjelasan untuk apa video itu dibuat. Namun, melihat bagaimana GL melaporkan akun-akun yang menyebarkan video itu

10 Komisioner Komisi Nasional Perempuan Siti Aminah Tardi menyebut GA dan MYD adalah korban penyebaran konten pribadi sehingga mestinya mendapat perlindungan hukum, bukan dijerat dengan pasal Undang-Undang Pornografi karena mereka membuat video tersebut untuk keperluan pribadi, https://news.detik.com/berita/d5314496/komnas-perempuan-gisel-korban-penyebaran-konten-intim-tangkap-penyebarnya, 30 Desember 2020, diakses 20 Maret 2021

$11 \mathrm{https} / /$ metro.tempo.co/read/1445867/pengakuan-tersangka-pemeras-video-syur-gabriella-larasati-cuma-iseng, dipublikasikan 25 Maret 2021, diakses 28 Maret 2021.

12 https://www.suara.com/entertainment/2021/03/01/155527/2-penyebar-video-syur-mirip-gabriella-larasatiditangkap-1-orang-residivis?page=all, dipublikasikan 1 Maret 2021, diakses 20 Maret 2021. 
sekaligus memerasnya, bisa disimpulkan bahwa video tersebut direkam bukan untuk konsumsi publik.

Dilihat dari sisi aktor, dalam video GA, GA adalah aktor yang berperan sebagai pengirim informasi kepada rekannya. Maka, aktor yang berperan sebagai pihak penerima informasi dalam konteks ini adalah rekan GA. Namun, video itu akhirnya menyebar ke Twitter sehingga posisi pengirim dan penerima informasi berubah. GA tidak lagi menjadi satu-satunya pengirim informasi, dan rekannya bukan lagi satu-satunya penerima informasi. Sedangkan dalam kasus video GL, posisi pengirim dan penerima informasi awal belum terungkap. Namun, ketika akhirnya video itu menyebar di media sosial, siapa saja yang berperan sebagai pengirim dan penerima informasi juga berubah karena melibatkan lebih banyak pihak.

Dari sisi atribut, dari berbagai berita yang ada, tampak jelas bahwa baik video GA maupun GL dibuat sebagai informasi yang bersifat pribadi. Itulah mengapa keduanya sama-sama melaporkan akun-akun yang menyebarkan video tersebut tanpa persetujuan mereka ke pihak kepolisian. Sedangkan dari sisi prinsip transmisi, tampak jelas pula bahwa kedua video itu dibuat untuk kalangan terbatas sehingga mestinya tidak boleh dibagikan kepada siapapun yang tidak ada keterkaitan langsung dengan pembuatnya.

Dari empat parameter tersebut, tampak bahwa ada elemen lain di luar kategori orang-orang yang menjadi pembuat dan penyebar video. Elemen yang terlibat dalam penyebaran video GA dan GL cukup kompleks, bukan lagi hanya sosok GA maupun GL, namun juga orang-orang yang menyebarkan dan menerima maupun mengakses video mereka. Selain itu, elemen lainnya adalah platform digital yang menjadi media penyebaran video, dalam hal ini Twitter. Dalam dua kasus tersebut, Twitter menjadi platform utama yang memungkinkan video itu viral dan bahkan menjadi trending topic dalam kasus video GA.

Dalam kerangka CI, Twitter merupakan salah satu aktor. Namun, posisinya dalam konteks pengirim dan penerima pesan tidaklah sejelas posisi GA/GL dan para pemilik akun penyebar video mereka. Meskipun demikian, peran Twitter sebagai entitas yang menjadi perantara distribusi pesan tak kalah penting dari aktor lainnya. Tanpa Twitter, kedua video itu belum tentu akan menjadi viral. $^{13}$

Terkait dengan konten yang mengandung unsur non konsensual, Twitter sebenarnya sudah punya kebijakan khusus. Dalam kebijakan yang dimuthakirkan pada November 2019 itu, Twitter menyatakan bahwa pengguna tidak diperbolehkan mengunggah maupun membagikan foto atau video intim seseorang yang dibuat ataupun didistribusikan tanpa persetujuan mereka. Bagi pengguna yang melanggar ketentuan tersebut, Twitter akan segera menutup secara permanen akun

13 Media online Tirto.id dalam "Pornografi Tetap Hidup dan Baik-Baik Saja di Semesta Twitter" yang dipublikasikan pada Juli 2019 menyebut bahwa di antara platform media sosial populer yang beroperasi di Indonesia, Twitter menjadi tempat terbaik konten mesum bertempat. Mencari konten pornografi di Twitter tidak sulit karena bisa dilakukan dengan menulis kata kunci di kolom pencarian. Lihat https://amp.tirto.id/pornografi-tetap-hidup-danbaik-baik-saja-di-semesta-twitter-ed17, Juli 2019, diakses 20 Maret 2020. 
yang teridentifikasi sebagai penyebar pertama konten tersebut. Twitter juga menyediakan mekanisme pelaporan bagi pengguna yang menemukan pelanggaran terhadap ketentuan ini. ${ }^{14}$

Akan tetapi, dengan kebijakan semacam itu pun, para pengguna Twitter masih tetap bisa mengunggah konten intin non konsensual. Selain itu, konten tersebut bisa bertahan cukup lama di dalamnya sehingga bisa diakses banyak orang dan menjadi viral. Itu menunjukkan bahwa kebijakan yang diterapkan Twitter dalam penyebaran video non konsensual belum bisa sepenuhnya melindungi korban, karena video yang diunggah tetap saja bisa diakses banyak orang. Ketika video itu akhirnya dihapus, dampak dari penyebaran video tersebut bagi korban sudah terlanjur sulit untuk diperbaiki.

Dari kacamata kerangka CI, langkah Twitter menerapkan kebijakan khusus untuk video non konsensual menunjukkan bahwa platform tersebut sebenarnya memiliki komitmen dalam menjaga privasi pengguna. Akan tetapi, dari kasus GA dan GL, terlihat bahwa kebijakan yang sudah disusun itu belum bisa sepenuhnya melindungi korban dari kasus penyebaran konten intim non konsensual. Mudahnya pengguna mengunggah konten intim non konsensual ditambah dengan durasi waktu video itu beredar sehingga bisa diakses banyak orang membuat platform ini turut berperan dalam memfasilitasi dan mendorong KBGO terhadap GA dan GL. Dalam kasus video GA, penghapusan video dilaporkan terjadi atas kebijakan dari Kementerian Komunikasi dan Informatika (Kominfo) yang mendesak pihak platform untuk menghapus konten. ${ }^{15} \mathrm{Hal}$ itu bisa berarti bahwa Twitter memerlukan desakan dari pihak yang punya wewenang, dalam hal ini Kominfo, untuk segera menghapus dan menghentikan peredaran video intim non konsensual.

\section{KESIMPULAN DAN REKOMENDASI}

Penggunaan kerangka CI untuk melihat kasus penyebaran video GA dan GL menunjukkan bahwa pihak perantara, dalam hal ini Twitter, memiliki peran dalam memfasilitasi serta mendorong terjadinya KBGO. Meskipun sudah memiliki kebijakan yang mengatur larangan konten intim non konsensual, video GA dan GL tetap beredar dan bahkan viral di Twitter. Hal itu menjadi bukti bahwa pihak platform digital selaku perantara pertukaran informasi dan komunikasi memang punya peran signifikan bagi munculnya kasus-kasus KBGO yang menimpa pengguna, khususnya perempuan.

Selain bisa mengevaluasi norma informasional dalam berbagai konteks pertukaran pesan sehingga bisa mengungkap pelanggaran privasi oleh berbagai aktor, kerangka CI juga memiliki elemen preskripsi atau bisa memberikan petunjuk terkait pengaturan privasi (Nissenbaum, 2010: 190). Kerangka ini menitikberatkan pada ekspektasi setiap orang akan privasi dalam konteks tertentu.

14 Lihat https://help.twitter.com/en/rules-and-policies/intimate-media diakses pada 28 Maret 2021

15 Berdasarkan penelusuran berita di media online, penulis tidak menemukan berita tentang permintaan GA maupun GL terhadap Twitter untuk menurunkan video yang terkait dengan mereka. Kebijakan untuk menurunkan/menghapus video tersebut berasal dari Kominfo yang kemudian mengkoordinasikannya dengan pihak Twitter, https://www.cnnindonesia.com/teknologi/20201107182002-185-567144/kominfo-take-downvideo-vulgar-mirip-gisel-di-medsos, 17 November 2020, diakses pada 20 Maret 2021. 
Dengan demikian, kerangka ini bisa diterapkan untuk menyusun kebijakan privasi yang mempertimbangkan berbagai konteks. Dalam hal ini, menanyakan harapan setiap orang akan makna privasi baginya menjadi perlu dilakukan.

Jika dikaitkan dengan peran perantara, seperti halnya teknologi berbasis internet yang terus berkembang, mereka bisa menjadi pihak yang memfasilitasi dan mendorong KBGO atau sebaliknya menjadi pihak yang turut dalam upaya mencegah dan mengeliminasi KBGO. Untuk itu, pengelola platform digital yang berperan sebagai perantara pertukaran pesan perlu didorong untuk memahami kerangka CI sehingga bisa menerapkannya guna mengevaluasi kebijakan privasi maupun syarat dan ketentuan layanannya, kemudian merevisinya ke dalam kebijakan baru yang lebih sensitif terhadap hak-hak perempuan dan kelompok gender minoritas lainnya.

Tentu saja, meminta pihak perantara untuk mengubah kebijakannya bukan hal yang mudah dilakukan. Berbagai pihak perlu bergandengan tangan untuk menunjukkan bagaimana teknologi memiliki bias yang berdampak bagi masyarakat melalui berbagai studi. Studi-studi semacam itu akan menjadi landasan kuat untuk mendesak pihak perantara mengevaluasi sistem hingga kebijakan layanan dan privasinya di satu sisi, serta mendorong negara mengeluarkan regulasi yang mengatur tanggung jawab pihak perantara untuk melindungi keamanan data pengguna.

Pandemi telah mendorong masyarakat kian lekat dengan teknologi dan menggunakannya untuk berbagai keperluan hidup, mulai dari jual-beli, bekerja, belajar, serta mencari hiburan. Ke depan, teknologi akan semakin menjadi bagian penting dari keseharian masyarakat. Oleh karena itu, upaya mendesak pihak platform teknologi agar menerapkan kebijakan yang lebih bisa menjamin privasi pengguna menjadi kian penting untuk dilakukan supaya kasus kekerasan tidak terus meningkat.

\section{DAFTAR PUSTAKA}

Buku

Aghtaie, N \& Gangoli, G. Understanding Gender Based Violence, National and International Context. Oxon: Routledge, 2015.

Komnas Perempuan. "Perempuan dalam himpitan pandemi: Lonjakan kekerasan seksual, kekerasan siber, perkawinan anak, dan keterbatasan penanganan di tengah Covid-19." Catatan kekerasan terhadap perempuan tahun 2020, Komnas Perempuan, 2020.

Nissenbaum, Helen. Privacy in Context, Technology, Policy, and Integrity of Social Life. California: Stanford University Press, 2010.

Powell, Anastasia dan Henry, Nicola. Sexual Violence in A Digital Age. UK: Palgrave, 2017.

PurpleCode Collective. CTRL+ALT+DEL KBGO!. Jakarta: PurpleCode Collective, 2020.

Segrave, Marie dan Laura, Vitis. Gender, Technology and Violence. New York: Routledge, 2017 
Jurnal

Barth, Adam, Datta, Anupam, Mitchell, John C, dan Nissenbaum, Helen. "Privacy and Contextual Integrity: Framework and Applications." 2007. Diterbitkan di "The Logic of Privacy," The Economist, January 2007, Proceedings of the IEEE Symposium on Security and Privacy, May 2006, tersedia di SSRN: https://ssrn.com/abstract=2567438.

Chadha, Kalyani, Steiner, Linda, Vitak, Jessica, dan Ashktorab, Zahra. "Women's Responses to Online Harassment”. International Journal of Communication, 14 (2020), hal: 239-257.

Christian, Jordy Herry. "Sekstorsi: Kekerasan berbasis gender online dalam paradigma hukum Indonesia." Binamulia Hukum Vol 9 No 1, Juli 2020, hal: 83-92, https://doi.org/10.37893/jbh.v9i1.103

Friedman, Bayta \& Nissenbaum, Helen. "Bias in Computer Systems." ACM Transactions on Information System Vol.14, No. 3, Juli 1996, hal: 330-347.

Henry, Nicola dan Powell, Anastasia. "Beyond the 'Sext': Technology Facilitated Sexual Violence and Harassment against Adult Women." Australian \& New Zealand Journal of Criminology, 2014, 48(1) :104-18, https://doi.org/10.1177/0004865814524218

Jatmiko, Iqbal M, Syukron, Muh, dan Mekarsari, Yesi. "Covid-19, Harrasment and Social Media: A Study of Gender-based Violence facilitated by Technology During the Pandemic." The Journal of Society and Media, October 2020, Vol. 4(2): 319-347, http://journal.unesa.ac.id/index.php/jsm/index, doi: 10.26740/jsm.v4n2.p319-347

Kumar, Priya C, Subramaniam, Mega, Vitak, Jessica, Clegg, Tamara L, dan Chetty, Marshini. "Strengthening Children's Privacy Literacy through Contextual Integrity." Media and Communication, Volume 8, Issue 4, hal: 175-184, doi:10.17645/mac.v8i4.3236

Mason, C dan Magnet, Shoshana. "Surveillance Studies and Violence Against Women." Surveillance \& Society 10 (2), 2012, hal: 105-118.

Ojanen, Timo Tapani, Boonmongkon, Pimpawun, Samakkeekarom, Ronnapoom, Samoh, Nattharat, Cholratana, Mudjalin, dan Guadamuz, Thomas Ebanan. "Connections Between Online Harassment and Offline Violence among Youth in Central Thailand". Child Abuse Neglect 2015, June 44, hal: 159-169, doi:10.1016/j.chiabu.2015.04.001.

Ratnasari, Eny, Sumartias, Suwandi, dan Romli Rosnandar. "Social Media, Digital Activism, and Online Gender-Based Violence in Indonesia." Nyimak Journal of Communication Vol.5, No.1, March 2021, hal: 97-116.

Sar, Rath Kanha dan Al-Saggaf, Yeslam. "Applying Contextual Integrity to the contest of social networking sites tracking.” Dalam S.R.S. Rogerson (Ed.), ETHICOMP 2013: Possibilities of ethical ICT, hal: 413-418. 
Semenzin, Silvia dan Bainotti, Lucia. "The use of Telegram for non-consensual dissemination of intimate images: gendered affordances and the construction of masculinities." SocArXiv, 2020, April 18, doi:10.31235/0sf.io/v4f63.

Nyst, Carly. "Internet intermediaries and violence against women online YouTube: A case study". Association for Progressive Communications (APC), 2014.

Suzor, Nicolas, Dragiewicz, Molly, Harris, Bridget, Gillett, Rosalie, Burgess, Jean, dan Van Geelen, Tess. "Human Rights by Design: The Responsibilities of Social Media Platforms to Address Gender-Based Violence Online." Policy and Internet, September 2018, doi:10.1002/poi3.185.

Werbin, K, Lipton, Mark dan Bowman, MJ. "The contextual integrity of the closet: Privacy, data mining and outing Facebook's algorithmic logics." Queer Studies in Media \& Popular Culture, Volume 2 Number 2, 2017, doi: 10.1386/qsmpc.2.1.29_1

Vitis, Laura \& Gilmour, Fairleigh. "Dick pics on blast: A womans resistance to online sexual harrasment using humour, art and Instagram." Crime Media Culture 13 (3), Juni 2016, doi:10.1177/1741659016652445

Artikel Online

Ahsinin, Adzkar. "Policy Brief Tanggung Jawab Perantara dalam Tata Kelola Konten Internet", Policy Brief, 2017. Elsam.

APJII. "Survei Pengguna Internet APJII 2019-Q2 2020: Ada Kenaikan 25,5 Juta Pengguna Internet Baru di RI." Buletin APJII Edisi 74, November 2020, hal: 1.

Cnnindonesia.com. “Kominfo ‘Take Down’ Video Vulgar Mirip Gisel di Medsos.” Dipublikasikan $7 \quad$ November 2020, diakses $20 \quad$ Maret 2021. https://www.cnnindonesia.cim/teknologi/20202207182002-185-567144/kominfo-takedown-video-vulgar-mirip-gisel-di-medsos.

Detik.com. "Timeline Kasus Video Syur Hingga Akhirnya Gisel Diperiksa Polisi.” Dipublikasikan 17 November 2020, diakses p20 Maret 2021. https://news.detik.com/berita/d5258259/timeline-kasus-video-syur-hingga-akhirnya-gisel-diperiksa-polisi.

Detik.com. "Komnas Perempuan: Gisel Korban Penyebaran Konten Intim, Tangkap Penyebarnya." Dipublikasikan 30 Desember 2020, diakses 20 Maret 2021. https://news.detik.com/berita/d5314496/komnas-perempuan-gisel-korban-penyebaran-konten-intim-tangkap-penyebarnya.

Kompas.com. "Artis Gisel Anastasia Ditetapkan sebagai tersangka Kasus Video Syur." Dipublikasikan 29 Desember 2020, diakses $20 \quad$ Maret 2021. https://megapolitan.kompas.com/read/2020/12/29/13573531/artis-gisel-anastasiaditetapkan-sebagai-tersangka-kasus-video-syur.

Suara.com. "2 Penyebar Video Syur Mirip Gabriella Larasati Ditangkap, 1 Orang Residivis." Dipublikasikan 1 Maret 2021, diakses $20 \quad$ Maret 2021. 
https://www.suara.com/entertainment/2021/03/01/155527/2-penyebar-video-syur-miripgabriella-larasati-ditangkap-1-orang-residivis?page=all .

Tempo.co. "Pengakuan Tersangka Pemeras Video Syur Gabriella Larasati Cuma Iseng." Dipublikasikan 25 Maret 2021, diakses 28 Maret 2021. https://metro.tempo.co/read/1445867/pengakuan-tersangka-pemeras-video-syur-gabriellalarasati-cuma-iseng.

Tirto.id. "Pornografi Tetap Hidup dan Baik-Baik Saja di Semesta Twitter". Dipublikasikan Juli 2019, diakses 20 Maret 2020. https://amp.tirto.id/pornografi-tetap-hidup-dan-baik-baiksaja-di-semesta-twitter-ed17.

Twitter. “Non-consensual nudity policy”. Dipublikasikan November 2019, diakses 18 Maret 2021. https://help.twitter.com/en/rules-and-policies/intimate-media.

UN Women. https://www.unwomen.org/en/what-we-do/ending-violence-againstwomen/faqs/types-of-violence 